\title{
MARKET APPROACH TO EDUCATIONAL SERVICES IN POLISH HIGHER EDUCATION
}

\begin{abstract}
The political changes that took place in Poland at the turn of the eighties and nineties of the twentieth century influenced not only the transformation of the political and economic systems, but also the majority of areas of social life. In higher education, the changes were the most dynamic. The purpose of this article is to look at the circumstances of the emergence of the higher education market in Poland and to consider the consequences of the market approach to the educational activity of universities.

The introduction of market mechanisms in Polish higher education and changes in the socioeconomic environment mean that universities that are not able to cope with competition and growing market requirements often face serious problems. Therefore, long-term strategic thinking and the use of tools to strengthen or at least maintain the current position of universities on the market is necessary.
\end{abstract}

Keywords: university market, Polish universities, educational service, higher education, market mechanism, communication with the environment.

\section{INTRODUCTION}

The political changes that took place in Poland at the turn of the 1980s and 1990s influenced not only the transformation of the political and economic systems, but also the majority of areas of social life. Higher education was one of the areas in which transformations, both institutional and quantitative ones, were the most dynamic. The legal basis for all transformations in this area was provided by the Act of September 12, 1990 on Higher Education (Journal of Laws No. 65 of 1990, Item 385 as amended), which contained regulations regarding the construction of a new model of higher education. The most important provision of this Act spoke of the abolition of the existing state monopoly in the creation and running of universities ${ }^{2}$, thus offering the possibility of establishing non-state universities ${ }^{3}$ and the introduction of paid forms of education in state institutions (evening, extramural and postgraduate studies). The aim of this article is to take a closer look at the circumstances of the

${ }^{1}$ Iwona Wojciechowska MA, The Faculty of Management, Department of Marketing, Rzeszów University of Technology, al. Powstańców Warszawy 12, 35-959 Rzeszów; e-mail: iwojciechowska@ prz.edu.pl, 17 7432522. ORCID: 0000-0003-0678-1066.

2 In Poland before 1990, only state universities existed, the only exception was the John Paul II Catholic University of Lublin (KUL).

3 The first non-state university in Poland was the Private School of Business and Administration in Warsaw (currently: the Private College of Business, Administration and Computer Techniques in Warsaw), founded by Tadeusz Koźluk by the decision of the Minister of Education of 29 June 1991. 
emergence of higher education market in Poland and to consider the consequences of a market-based approach to the educational activity of universities. To achieve the set goal, literature on the subject, legal acts and statistical data were analysed.

\section{BEGINNINGS OF THE HIGHER EDUCATION MARKET IN POLAND}

Before 1990 in Poland, we had a small number of universities, transparency of structures, unified curriculum content, as well as competition-free centrally funded higher education (See: Dybaś, Dziemianowicz-Bąk et al., 2012; Kaczmarczyk, 2013). As noted by M. Kaczmarczyk (2013), the Act introduced in 1990 and the formal and legal changes resulting from it, became the basis for building a completely different from the previous one model of higher education, based on reformed state and emerging non-state universities. The development of non-state universities introduced market competition mechanisms to the field of social life, which until now had entirely been subordinated to state central planning and management (Waltoś, Rozmus [ed.], 2016). A. Buchner-Jeziorska (2005) writes directly about the more or less conscious (intentional) transformation of the higher education system into the market of educational services.

According to the general definition, the market is a place where demand and supply meet, at which the price is set. Otherwise, it is also the overall relationship between entities (sellers and buyers) participating in exchange processes (Wrzosek, 2012). By adapting this definition to the sphere of services, it can be specified that the services market is formed by relationships between entities providing services (service providers) and entities expressing interest in their purchase (recipients) (Czubała, Jonas et al., 2012).

If we assume that competition is also an inseparable element of the market, then the moment of implementation of the aforementioned Act can be regarded as the beginning of the existence of the market of educational services in higher education in Poland. A completely new phenomenon appeared in the functioning monolithic structure - competition, and the market rule of balancing demand and supply began to affect the forms of activity and the socio-economic condition of universities (Kaczmarczyk, 2013).

A. Buchner-Jeziorska emphasizes that the emergence of the market was the result of a number of phenomena and socio-economic processes directly or indirectly related to this area (Buchner-Jeziorska, 2005). According to the author, the direct reasons for the emergence of the higher education market should be sought in:

- complete lack of an idea for the state's education policy in the first half of the 1990s (the first, rather general document, which set out the assumptions for the state's education policy, was not developed until 1996),

- quick withdrawal of the state from the so-called soft financing of the public sector, which in the case of higher education has resulted in a drastic reduction in expenditure on this sphere, especially per student,

- introducing a market mechanism as the basic regulator of the functioning of higher education in Poland by enabling (pursuant to the Act of 1990) the establishment of non-state universities and charging fees for certain forms of education at state universities.

The indirect causes are:

- changes in the structure of demand for highly qualified staff, mainly in the field of business management, 
- propagated ideology of building market economy, the pillars of which were supposed to be business people (entrepreneurs, managers, financiers etc.),

- increase in the market value of higher education, defined as the correlation between education and the amount of income received,

- growing educational aspirations of the Polish society in connection with the widespread recognition of higher education as a chance for professional success and obtaining high income,

- entering of subsequent baby boom cohorts into the market of educational services in higher education.

It is worth noting that the higher education market due to applicable legal regulations and the type of services provided was and still is quite unusual. Firstly, because we cannot talk about a completely free market here, because the state defines the conditions for its functioning, has appropriate regulatory instruments and has the right to intervene in a situation when market mechanisms do not work properly (Drapińska [2011] writes about the so-called quasi-market, i.e. a state-controlled market), and secondly because, apart from paid services, there are also forms that do not require payment from the buyer (full-time studies in public universities) (See: Kulig, 2004; Drapińska, 2011).

\section{THE ESSENCE OF EDUCATIONAL SERVICE IN HIGHER EDUCATION}

Generally, educational services of universities are professional services provided by entities that must meet specific, legally regulated requirements, their provision process lasts for a long time and is complicated. It should be added that the recipient plays an important role in determining the final result, much depends on his approach to the subject of services and individual commitment. The mutual relations between the service provider and the recipient are of equal importance. The situation is specific because over several years, many people from various areas are involved in the process of providing educational services, many of whom have direct contact with and thus some impact on the student, so that they can affect the student's subsequent assessment of the quality of the service as a whole (Kulig, Nowaczyk, 2011).

As already mentioned, educational services are more complex and of a different character than most standard services. According to M. Szabłowski, among the phenomena that contribute to their difference are (Szabłowski, 2004):

- the dual role of a student who is at the same time a client and product: the university provides a student with educational service and offers a product - a graduate to the labour market,

- exceptionally high student participation in co-creating the service (prosumption),

- difficulty in determining by the candidate the expectations of the service and its quality - the candidates do not have sufficient knowledge to assess them properly,

- high mental pressure when choosing a university - this is not only a consumer's decision, but also life choice, not related to market behaviour,

- one-time use of the service - as a rule, studies are undertaken once in a lifetime, the change of studies results in a loss of part of money and student's own work invested,

- very long lead time compared to other services,

- complex decision-making process - decision assessment will take place in the distant future, it will be made from the perspective of the later career path and the situation on the labour market, 
- the ability to change expectations about the service while receiving it - this is a function of time and the student's personal development during studies,

- dilemma between the pursuit of knowledge (using the educational service in full) and the reluctance to put effort in studying,

- discrepancy between ambitions and level of self-esteem and the possibilities of achieving the expected results.

A. Drapińska, justifying the fact that the quality of higher education services can only be partially assessed while getting them, and full verification usually takes place only after they have been provided and usually from a longer time perspective, defines them as an experimental good (Drapińska, 2011).

As A. Kulig and G. Nowaczyk rightly note, educational services also have problems with standardization (Kulig, Nowaczyk, 2011). Of course, such attempts are made on many levels, because you can standardize procedures (e.g. documentation, applicable terms, etc.), content (curricula) or assessment methods, but it is difficult to introduce standards covering the level of knowledge, the appropriate ways of applying it, communication skills, etc. It is also difficult to precisely define all the elements that make up the university's service offer, the way it is shaped and perceived by the recipient. The starting point here are legal regulations that universities must comply with, but they only specify the basic functions of the educational service and still many areas remain underdefined (Kulig, Nowaczyk, 2011). Under the Act on Higher Education and Science (The Act of 20 July 2018 on Higher Education and Science, art. 11) the basic tasks of the university include:

- providing education in studies,

- providing post-graduate education or other forms of education,

- participating in scientific activity, providing research services and sharing the knowledge and technology with the economy,

- providing doctoral education,

- educating and promoting academic staff,

- creating conditions for the disabled to participate fully in the education process and scientific activities,

- raising students in a sense of responsibility for the Polish state, national tradition, strengthening the principles of democracy and respect for human rights,

- creating conditions for the development of students' physical culture,

- propagating and multiplying the achievements of science and culture, including collecting and sharing libraries, information and archives,

- acting for the benefit of local and regional communities.

\section{MARKET APPROACH TO EDUCATIONAL ACTIVITY OF UNIVERSITIES}

The market approach to education means that we are beginning to treat the activities of educational institutions, such as universities, as enterprises on the market (Ostaszewska, 2004), and students as the main (though definitely not the only one) group of clients. The concept of the education market includes assumptions about the mechanisms of functioning of education systems according to market rules, which are identified with the processes of adjusting supply to demand, competition and commercialization, i.e. profit-oriented activities (Szczepańska-Woszczyna, 2004). 
The dynamic development of universities in Poland at the end of the 20th century was a consequence of the emergence of the higher education market. Since entering into force in 1990 of the aforementioned Act on Higher Education, a rapid quantitative growth of this sector began, understood both as an increase in the number of universities and persons undertaking higher education. The period of the most dynamic development was in the years 1993-1998 when the largest number of non-state universities appeared. In the following years, this upward trend was systematically and clearly weakened, and since the academic year 2006/2007 there has been a more visible drop in the number of students (Szkoty wyżzze $i$ ich finanse $w 2017$ r., 2018, https). This is mainly due to the end of the baby boom of 1981-1985 and the fact that the studies were undertaken by the increasingly fewer graduates of upper-secondary schools. OECD forecasts say that this unfavourable trend will continue in the coming years and in 2025 the number of potential students in Poland will decrease by over $40 \%{ }^{4}$.

In addition to demographic factors that undoubtedly affect the increase in competition on the higher education market, it is also worth paying attention to other phenomena occurring in the environment not only of Polish universities, including ubiquitous scientific and technical progress, development of information technologies enabling the use of new ways of teaching (e-learning), unlimited access to information and general development of student awareness (Palacio, Meneses, Perez, 2002). These phenomena can pose a significant threat to many universities, but at the same time, when noticed and properly used, can also become a chance for development.

It is also worth emphasizing that as a result of joining the Bologna Process ${ }^{5}$, Polish universities have also become participants in the global market. The internationalization of this educational sector and the increase in student mobility mean above all the internationalization of the learning process. As a consequence, we can observe not only the enhanced competition between national universities, but also with those abroad. On one hand, it gives a chance to attract students from other countries, on the other, it creates a threat, because an increasing number of Poles go to study abroad (Drapińska, 2011).

As the above considerations show, the higher education system in Poland has changed dynamically over the last few decades. Initial transformations resulting from the emergence of the higher education market focused primarily on increasing access to higher education, often ignoring the qualitative aspect. Gradually, however, the higher education sector from

\footnotetext{
${ }^{4}$ Change in \% compared to the year 2005; see: (Higher Education to 2030, Vol. 1: Demography (2008), OECD [Access: 27.07.2018]. Access on the internet: www.oecd.org/dataoecd/48/6/ 41939423.pdf).

5 The implementation of the Bologna Process was initiated in 1999 by ministers from 29 European countries (including Poland) signing a document later known as the Bologna Declaration. The essence of this process was to be the rapprochement of higher education systems of European countries, ultimately leading to the creation of European Higher Education Area - EHEA in 2010. According to the assumptions, the detailed implementation of this process was to include: the introduction of a system of transparent and comparable degrees through the implementation of a diploma supplement, the adoption of an education system based on two / three levels of education, widespread use of the credit point system (ECTS - European Credit Transfer System), promotion of student, academic teachers, researchers and administrative staff mobility, promotion of European cooperation in increasing the quality level of higher education, promotion of the European dimension of higher education, particularly in the field of professional development, mobility and integrated curricula, training and research.
} 
the bidding market became a buyer's market (Waltoś, Rozmus [ed.], 2016), which also forced a change in the current focus on quantity and a stronger shift towards quality. This became most evident from the 2006/07 academic year, when market saturation took place and the increasingly fierce competition between universities could be clearly seen. It can also be assumed that further processes of consolidation and closedown of some universities in our country are inevitable.

\section{CONCLUSIONS}

The university environment is constantly changing. The changes are so dynamic that universities must react flexibly and adapt to them on a regular basis. Both the introduction of market mechanisms in Polish higher education and the phenomena presented above cause that universities that are unable to cope with competition and increasing market demands often face serious problems. Therefore, long-term strategic thinking and the use of tools enabling strengthening or at least maintaining the current position of the university on the market is necessary. A particularly important issue here seems to be the knowledge of the factors that determine the competitiveness of an educational product, i.e. its market attractiveness for potential buyers.

An opportunity for the university to survive in this undoubtedly difficult period (demographic decline, market saturation, increased competition) and at the same time a partial alternative to the decreasing number of high school graduates may also be the development of an additional offer in the form of post-graduate studies or other forms of training. Broadly understood scientific and technological progress enforces the need for continuous improvement (implementation of the concept of Life Long Learning), providing access to various forms of study (first, second, third degree, postgraduate studies, MBA, courses, training) seems to be the right direction. In such a situation, building long-term relationships with students and an appropriate way of communicating with them using communication channels properly selected for the recipients are of great importance. These are the students who may be the first to be interested in updating and developing their knowledge and skills. Satisfaction with education during first and second-cycle studies and building strong relationships with students, and then skilfully supporting them with graduates, may result in their return to other forms of education. In this way, the so-called brand ambassadors, i.e. people recommending particular services in their immediate surroundings, appear.

\section{REFERENCES}

Buchner-Jeziorska, A. (2005). Rynek czy system: Szkolnictwo wyższe w Polsce okresu transformacji [in:] Buchner-Jeziorska, A., ed., Szkoła sukcesu czy przetrwania - szkolnictwo wyższe w Polsce, Warszawa: Oficyna Wydawnicza SGH.

Czubała, A., Jonas, A. et al. (2012). Marketing ustug. Warszawa: Wydawnictwo Wolters Kluwer.

Drapińska A. (2011). Zarządzanie relacjami na rynku ustug edukacyjnych szkót wyższych. Warszawa: PWN.

Dybaś, M., Dziemianowicz-Bąk, A. et al. (2012). Szkolnictwo wyższe [in:] Raport o stanie edukacji 2011. Kontynuacja przemian. Warszawa: Instytut Badań Edukacyjnych. Acces on the internet: http://eduentuzjasci.pl/component/content/article/2-uncategorised/733-raport-o-stanieedukacji-2011.html?showall=\&start=1. 
Higher Education to 2030, Vol. 1 Demography, OECD, 2008. Access on the internet: www.oecd.org/dataoecd/48/6/41939423.pdf.

Hnatyszak, O. (2018). Uczelnia nowej generacji-redefinicja instytucjonalna uczelni. „Nierówności Spoteczne a Wzrost Gospodarczy”, nr 54 (2/2018).

Kaczmarczyk, M. (2013). Public relations szkót wyższych. Model komunikowania się z otoczeniem $w$ demokratycznej przestrzeni publicznej. Sosnowiec-Katowice: Oficyna Wydawnicza „Humanitas” i Wydawnictwo Naukowe „Śląsk”.

Kulig, A., Nowaczyk, G. (2011). Redefinicja usług szkół wyższych [w:] Nowaczyk, G., Sobolewski D., ed., Marketing $w$ szkole wyższej. Przemiany w orientacji marketingowej. Poznań: Wydawnictwo Wyższej Szkoły Bankowej

Kulig, A. (2004), Rynek usług edukacyjnych w Polsce na poziomie wyższym [in:] Nowaczyk, G., Kolasiński, M., ed., Marketing szkót wyższych. Poznań: Wydawnictwo Wyższej Szkoły Bankowej.

Ostaszewska, A., Kontrowersje wokót interpretacji jakości ksztatcenia w szkolnictwie wyższym [in:] Nowaczyk, G., Kolasiński, M., ed., Marketing szkót wyższych. Poznań: Wydawnictwo Wyższej Szkoły Bankowej.

Palacio, A.B., Meneses, G.D. et al. (2002). The configuration of the university image and its relationship with the satisfaction of students. "Journal of Educational Administration", Vol. 40, No. 5.

Szabłowski, M. (2004). Poziom nauczania jako dylemat marketingowy uczelni [in:] Nowaczyk, G., Kolasiński, M., ed., Marketing szkót wyższych. Poznań: Wydawnictwo Wyższej Szkoły Bankowej.

Szczepańska-Woszczyna K. (2004). Wyksztatcenie absolwentów elementem ksztattowania pozycji rynkowej uczelni [in:] Nowaczyk, G., Kolasiński, M., ed., Marketing szkót wyższych. Poznań: Wydawnictwo Wyższej Szkoły Bankowej.

Szkoty wyższe $i$ ich finanse w 2017 r. (2018). GUS, Warszawa. Access on the internet: https://stat.gov.pl/download/gfx/portalinformacyjny/pl/defaultaktual-

nosci/5488/2/14/1/szkoly_wyzsze_i_ich_finanse_w_2017_r.pdf.

The Act of 12 September 1990 on Higher Education (Dz.U. z 1990 r., nr 65, poz. 385 ze zm. akt archiwalny. Access on the internet: http://prawo.sejm.gov.pl/isap.nsf/DocDetails.xsp?id= WDU19900650385.

The Act of 20 July 2018 on Higher Education and Science (Dz.U. z 2018 r., poz. 1668). Access on the internet: http://prawo.sejm.gov.pl/isap.nsf/download.xsp/WDU20180001668/O/ D20181668.pdf

Waltoś, S., Rozmus, A., ed. (2016). Szkolnictwo wyższe w Polsce. Ustrój, prawo, organizacja. Warszawa: Wydawnictwo Wolters Kluwer.

Wrzosek, W. (2012). Funkcjonowanie rynku. Warszawa: PWE.

DOI: $10.7862 / \mathrm{rz} .2019 . \mathrm{mmr} .30$

The text was submitted to the editorial office: December 2019.

The text was accepted for publication: January 2020. 
